\title{
Clinico-Haemato-Biochemical Profile of Dogs with Urinary Tract Infection: A Retrospective Study of 32 Cases (2010-2012)
}

\author{
S. Yogeshpriya*, Usha Narayana Pillai, S. Ajithkumar and Madhavan Unny \\ Department of Veterinary Medicine, Veterinary College and Research Institute, Orathanadu, \\ Thanjavur, Tamilnadu-614625, India \\ Department of Clinical Veterinary Medicine, College of Veterinary and Animal Sciences, \\ Mannuthy, Thrissur, Kerala, India \\ *Corresponding author
}

\begin{tabular}{|l|}
\hline Ke y w o r d s \\
$\begin{array}{l}\text { Urinary tract } \\
\text { infection, } E \text {. coli, } \\
\text { Cystocentesis, C - } \\
\text { reactive protein }\end{array}$ \\
\hline Article Info \\
\hline $\begin{array}{l}\text { Accepted: } \\
18 \text { August } 2018 \\
\text { Available Online: } \\
\text { 10 September } 2018\end{array}$ \\
\hline
\end{tabular}

\section{Introduction}

Bacterial urinary tract infection usually results from ascending infection from normal skin and gastrointestinal tract flora which may overcome the normal urinary tract defences that prevent colonization. Whether clinical signs are present or not, the consequences of untreated Urinary tract infection (UTI) included urolithiasis, prostatitis, septicemia and pyelonephritis with scarring and concentration were observed.
The main object of this study was to determine the urinary tract infections among dogs that were admitted to the University Veterinary Hospitals at Kokkalai and Mannuthy during 2 year period from 2010 to 2012. A total of 2545 dog cases, 66 cases with clinical signs suggestive of urinary tract infections were selected. The major clinical signs in the study were pyuria, stranguria, haematuria, anorexia, pollakiuria, foul smelling urine or dark yellow urine and emesis. Elevated rectal temperature, respiratory rate and tachycardia were observed on general clinical examination. The most common bacteria isolated from urine sample were E.coli followed by Proteus mirabilis, Staphylococcus aureus, Klebsiella pneumoniae and Streptococci spp. Ultrasonographically, thickness of the urinary bladder was the most common feature. Hyperechoic particles in the urinary bladder, thickened kidney cortex, hyperechoic kidney with reduced corticomedullary distinction and hyperechoic renal pelvis and diffuse increase in echogenicity of prostatic parenchyma were also observed. Haematobiochemical changes such as markedly increased ESR values, total leucocyte count and neutrophils values, hypoalbuminemia and increased urea

\section{A B S T R A C T}

eventually kidney failure. In intact male dogs, UTI frequently extends to the prostate gland (Yogeshpriya et al., 2016a). Due to the blood prostate barrier, it is difficult to eradicate bacteria from the prostate gland, and they may reinfect the urinary tract, causing a systemic bacteraemia, infect the reproductive tract, or cause a local infection within the prostate and eventually cause an abscess (Dowling, 1996). It has been estimated that $10 \%$ of all canine patients attended by veterinarians for any 
reason have UTI in addition to the problems for which they are presented (Yogeshpriya $e t$ al., 2016b).

The present study was conducted to ascertain the prevalence of urinary tract infections in dogs and their clinical, haematological and biochemical evaluations compared to other apparently healthy dogs that were admitted to the University Veterinary Hospitals at Kokkalai and Mannuthy during 2 year period from 2010 to 2012. Also, study the antibiotic susceptibility and ultrasonographic findings of dogs affected with UTI.

\section{Materials and Methods}

The study was conducted in the Department of Clinical Veterinary Medicine, College of Veterinary and Animal Sciences, Mannuthy during the period of 2010 to 2012. Dogs brought to the University Veterinary Hospital, Kokkalai and Mannuthy with clinical signs suggestive of urinary tract infections were selected and utilized for the present study. A total of 2545 cases, 66 cases with clinical signs suggestive of urinary tract infections were selected. Out of these 66 cases, 32 cases were confirmed as UTI based on urinalysis.

\section{Clinical examination}

Each dog was subjected to a detailed clinical examination and thoroughly evaluated for its general condition, inspection of mucous membranes, hydration status, signs of pain, pyuria, stranguria, haematuria, anorexia, pollakiuria, foul smelling urine, dark yellow urine and emesis.

\section{Haemato-biochemical analysis}

Relevant clinical materials were collected at the time of admission. Five $\mathrm{ml}$ of whole blood was collected from saphenous or cephalic vein of the selected dogs in dry glass vials containing EDTA@ 1-2mg/ ml as anticoagulants (Benjamin, 1985). About $10 \mathrm{ml}$ of blood was collected in another vial on the day of admission to separate serum for biochemical examination. Sera thus separated were stored at $-20^{\circ} \mathrm{C}$ till further analysis. Total erythrocyte count, hemoglobin, volume of packed red cells, total leukocyte count, differential leukocyte count and platelet count were estimated as per the method (Schalm et al., 1975). Blood urea nitrogen, serum creatinine, serum total proteins, serum albumin, serum globulin and $\mathrm{A}$ : $\mathrm{G}$ ratio on first day using semiautomatic analyzer, as per the manufacturer's instructions and using standard kits. Serum C-reactive protein was estimated using the turbidimetric assay using standard kits.

\section{Quantitative urine culture}

A serial dilution of urine sample ranging from $10^{-1}$ to $10^{-6}$ was made, and $0.1 \mathrm{ml}$ of inoculum of each dilution in duplicate was placed on the surface of the each nutrient agar plate and it was then spread uniformly with the help of a flame- sterilized nichrome wire, bent in a Lshape. All agar plates were incubated at $37^{\circ} \mathrm{C}$ for 24 hours. Average number of CFU/plate was calculated from this dilution, and after applying the dilution factor, the number of bacteria was expressed as CFU/ml (Gatoria, 2006).

Individual colonies were confirmed using standard microbiological method which includes gram staining, colonial morphology on media, growth on selective media, lactose fermentation, catalase, oxidase, coagulase, indole, citrate utilization and urease tests (Barrow and Feltham, 1993).

\section{Antibiotic susceptibility testing}

Antibiotic sensitivity of the urine samples was obtained by using disk-diffusion (Kirby-Bauer 
method) method as per Cruickshank (1975) and Pierce-Hendry and Dennis (2010).

\section{Statistical analysis}

The collected haematology and biochemical values were recorded and to Microsoft excel $2010^{\circledR}$ spreadsheet, stored separately and exported to analytical software using Students ' $t$ ' test. Values of $p \leq 0.05$ were considered as statistically significant.

\section{Results and Discussion}

Clinical signs were included pyuria $(42.85 \%)$, stranguria $(35.71 \%)$, haematuria $(28.57 \%)$, anorexia $(28.57 \%)$, pollakiuria $(25 \%)$, foul smelling urine $(17.85 \%)$, dark yellow urine $(14.28 \%)$ and emesis (3.87 \%). General physical examination of dogs showed mean temperature of $103.01 \pm 1.15\left({ }^{\circ} \mathrm{F}\right)$. Abdominal pain was observed in 6 out of 32 dogs. The mean heart rates (beats/ min) and respiratory rates (beats/ min) on the day of admission were $120 \pm 12$ and $25 \pm 13$ respectively. Quantitative bacteriological cultures of urine specimens from dogs with UTIs were obtained. More than $10^{4} \mathrm{CFU} / \mathrm{ml}, 10^{5} \mathrm{CFU} / \mathrm{ml}$ and $10^{6} \mathrm{CFU} / \mathrm{ml}$ were observed in 28.57, 53.57 and $17.85 \%$ cases respectively. The vast majority of female dogs yielded $>10^{5}$ CFU/ml $(39.28 \%)$ followed by $>10^{4}(10.71$ $\%)$ and $10^{6}(7.14 \%)$ CFU $/ \mathrm{ml}$. Bacteria isolated from male dogs were in the order of $>$ $10^{4}(17.85 \%), 10^{5}(14.28 \%)$ and $10^{6} \mathrm{CFU} / \mathrm{ml}$ $(10.71 \%)$ respectively. The most common bacteria isolated from urine sample were E.coli $(78.57 \%)$ followed by Proteus Mirabilis (7.14 \%), Staphylococcus aureus (7.14\%), Klebsiella pneumoniae $(3.57 \%)$ and Streptococci spp. $(3.57 \%)$. The haematobiochemical evaluation of dogs with UTIs were compared to the apparently healthy dogs and statistically analyzed (Table 1). The thicknesses of the wall of the urinary bladder was calculated in 12 out of 32 dogs diagnosed with UTIs (Plate.2). Thickness in two dogs were $>2 \mathrm{~mm}$ diameter in thickness across all over the wall whereas one dogs was $>2 \mathrm{~mm}$ in cranio ventral region and caudal region was < $2 \mathrm{~mm}$. Rest of the dogs, the bladder wall was $<2 \mathrm{~mm}$ in thickness. Hyperechoic area within the bladder was observed in 12 cases. Normal in remaining cases. Cultural examination of urine samples of animals were negative in all cases by $10^{\text {th }}$ day but treatment were continued for 14 days.

Clinical signs observed in the present study were pyuria, stranguria, haematuria, anorexia, pollakiuria, foul smelling urine, dark yellow urine and emesis. This is in agreement with Dunning and Stonehewer (2002) and Papini et al., (2006). Major clinical signs observed in this present study might be due to lower UTIs and which were in accordance with the studies of Bartges (2004). General physical examination findings such as abdominal pain on palpation, tachycardia (>120 beats/min), respiratory rate of $>20$ breaths / min and body temperature of $>39.2^{\circ} \mathrm{C}$ were suggestive of systemic inflammatory response syndrome (Fransson et al., 2007). In the present study all urine samples were collected by cystocentesis as opined by Bubenik et al., (2007) who reported E.coli and Proteus spp. were significantly more frequent in noncatheterized urine samples in dogs. The most common bacteria isolated from urine sample were E.coli $(78.57 \%)$ followed by Proteus mirabilis (7.14 \%), Staphylococcus aureus (7.14\%), Klebsiella pneumoniae (3.57\%) and Streptococci spp. (3.57\%). The percentage of isolates obtained in this study were near to the percentages obtained by Ball et al., (2008) who reported 55.6, 6.9, 3.2, 1.2 and $4.2 \%$ respectively.

In this study, all urine samples were obtained by cystocentesis and observed bacterial count of more than $>10^{4}$ and $>10^{6}$ which indicated significant bacteriuria as opined by Dunning 
and Stonehewer (2002) and Bartges (2004) who concluded that $>10^{3} \mathrm{CFU} / \mathrm{ml}$ was indicative of significant bacteriuria in dogs. However, Gatoria et al., (2006) noticed that isolation of more than $10^{2} \mathrm{CFU} / \mathrm{ml}$ in a urine sample obtained by cystocentesis could be indicative of UTIs. Among results of canine urine collected by cystocentesis, most female dogs yielded $>10{ }^{5} \mathrm{CFU} / \mathrm{ml}$ as reported by Ling et al., (2001), Gatoria et al., (2006) and Papini et al., (2006) who observed > $10^{5}$ $\mathrm{CFU} / \mathrm{ml}$ in urine cultures with UTIs. The present study showed that the vast majority of canine UTIs were caused by a single bacterial species. Similar observations were reported by Cetin et al., (2003) and Gatoria et al., (2006).

Table.1 Haemato- biochemical parameters of dogs with urinary tract infections

\begin{tabular}{|c|c|c|c|}
\hline Attributes & $\begin{array}{l}\text { Apparently healthy } \\
\text { dogs }(n=32)\end{array}$ & $\begin{array}{l}\text { UTIs dogs } \\
(\mathrm{n}=32)\end{array}$ & 'p' value \\
\hline $\mathrm{TP}(\mathrm{g} / \mathrm{dl})$ & $7.21 \pm 0.3$ & $7.08 \pm 0.7$ & 0.11 \\
\hline Albumin (g/dl) & $3.87 \pm 0.22$ & $2.9 \pm 0.6$ & 0.81 \\
\hline Globulin (g/dl) & $3.34 \pm 0.01$ & $4.19 \pm 0.8$ & 0.85 \\
\hline BUN (mg/dl) & $23.67 \pm 2.67$ & $42.28 \pm 32.9$ & 0.004 \\
\hline Creatinine (mg/dl) & $1.02 \pm 0.9$ & $1.8 \pm 1.5$ & 0.72 \\
\hline CRP(mg/l) & $7.89 \pm 2.3$ & $8.35 \pm 4.2$ & 0.43 \\
\hline Haemoglobin (g\%) & $13.42 \pm 2.3$ & $13.11 \pm 2.7$ & 0.31 \\
\hline Red Blood Cell $\left(\mathrm{mill} / \mathrm{mm}^{3}\right)$ & $6.00 \pm 1.5$ & $5.73 \pm 1.6$ & 0.24 \\
\hline Volume of Packed Red Cells (\%) & $40.65 \pm 6.7$ & $39.66 \pm 8.2$ & 0.29 \\
\hline $\begin{array}{l}\text { Erythrocyte Sedimentation Rate } \\
(\mathrm{mm} / \mathrm{hr})\end{array}$ & $13.64 \pm 9.2^{\mathrm{a}}$ & $25.83 \pm 26.3^{\mathrm{a}}$ & $0.008^{*}$ \\
\hline Total Leukocyte Count $\left(/ \mathrm{mm}^{3}\right)$ & $11813.13 \pm 2354.2$ & $15571.88 \pm 4909.2$ & 0.32 \\
\hline Neutrophils (\%) & $66.78 \pm 5.4^{\mathrm{a}}$ & $76.22 \pm 10^{\mathrm{a}}$ & $0.001^{*}$ \\
\hline Lymphocytes (\%) & $24.56 \pm 10.2$ & $19.98 \pm 0.8$ & 0.76 \\
\hline Eosinophils (\%) & $2.23 \pm 4.3$ & $1.94 \pm 1.5$ & 0.33 \\
\hline Monocytes (\%) & $2.66 \pm 0.4$ & $1.28 \pm 0.6$ & 0.76 \\
\hline Platelets $\left(/ \mathrm{mm}^{3}\right)$ & $2.96 \pm 0.8$ & $2.66 \pm 1.1$ & 0.30 \\
\hline Mean Corpuscular Volume (fl) & $74.43 \pm 0.9$ & $70.29 \pm 10.3$ & 0.87 \\
\hline Mean Corpuscular Haemoglobin (pg) & $25.67 \pm 1.1$ & $23.21 \pm 3.6$ & 0.38 \\
\hline $\begin{array}{l}\text { Mean Corpuscular Haemoglobin } \\
\text { Concentration (\%) }\end{array}$ & $35.09 \pm 2.3$ & $33 \pm 1.7$ & 0.81 \\
\hline
\end{tabular}

Means with superscripts are significantly different (5\% level)

Statistical analysis of haematological parameters did not reveal any significant difference between the dogs with UTIs and healthy dogs except markedly increased ESR values. Increased ESR observed in the present study suggested of chronicity of infection as opined by Andonova et al., (2010). There was a significant elevation $(\mathrm{p} \leq 0.05)$ of neutrophils when compared to healthy control group.
Leucocytosis, neutrophilia and lymphopenia might occur due to variable extent of stress induced by bacterial organisms in the urinary tract as well as a sign of manifestation of body defense mechanism against bacterial infection. The mean values of eosinophils, basophils, monocytes and platelets values were within the normal range. 
Statistical analysis of biochemical values showed no significant changes among these groups. Hypoalbuminemia was observed in this study might be due to loss of albumin through the urine (Squires, 1994). Increased globulin concentrations were seen in present study agreed with observations made by Georgieva et al., (2008). Decreased production and increased loss of albumin during inflammation was responsible for mild hypoalbuminemia which might be accompanied by normal or even elevated serum globulin concentrations (Throop et al., 2004 and Fransson et al., 2007). Mild increase of creatinine value in affected dogs might be due to impending azotemia (Blanco and Bartges, 2001). CRP was gaining an important position in veterinary point-of-care settings to more effectively take care of diseased dogs with suspected inflammatory diseases. Another aim with using dCRP as a diagnostic marker is to monitor the efficacy of antibiotic treatment. Leveille et al., (1998) opined that cystitis was recognized by a diffuse thickening of the bladder wall. Cranioventral thickening of the bladder wall was frequently observed in chronic cystitis. This was in accordance with the present study where cranio ventral bladder wall thickening was observed in one case along with thickening of caudal region. Similar findings were also reported by Antony (2004). In dogs with UTIs, the observed thickness of urinary bladder wall were $>2 \mathrm{~mm}$ in diameter as opined by Mantis (2008) who reported thickness of distended bladder wall should not exceed $2 \mathrm{~mm}$ in normal healthy animals. This was in agreement with the findings of the present study.

The urine was usually echogenic in 12 out of 28 cases and gives a swirling effect. This was because of the presence of cells or high protein content. Kealy et al., (2011) also observed similar findings in UTIs. The author also reported that the sediment might be seen in the dependent portion of the bladder. When disturbed, it moved as a cloud and resettled with a distinct horizontal border. This might be the reason for hyperechoic area within the bladder in $42 \%$ of cases.
The present study showed that the vast majority of canine UTIs were caused by a single bacterial species. In this study, all urine samples that were positive for bacterial cultures obtained by cystocentesis quantitatively yielded a bacterial count between more than $>10^{4}$ and $>10^{6}$ which is indicative of significant bacteriuria. Predominant sonographic finding in case of urinary tract infection was thickening of urinary bladder and hyperechoic area within the bladder. Haematobiochemical values were unrewarding to diagnose urinary tract infections. However, markedly increased ESR values observed indicated a presence of severe infection. The serum CRP value was normal in uncomplicated UTIs.

\section{References}

Andonova, M., Dimitritcha, D. and Borissov, I. 2007. Nonspecific defence mechanisms in dogs during experimental staphylococcus infection. Vet. Glasnik. 65: 25-41.

Antony, S. 2004. Ultrasonographic investigation of urinary tract disorders in dogs. M.V.Sc Thesis submitted to the Kerala Agricultural University, Trichur, 96p.

Ball, K.R., Rubin, J.E., Chirino-Trejo, M. and Dowling, P.M. 2008. Antimicrobial resistance and prevalence of canine uropathogens at the western college of veterinary medicine veterinary teaching hospital, 2002-2007. Can. Vet. J. 49: 985990.

Barrow, G.I. and Feltham, R.K.A. 1993. Cowan and Steel's manual for the identification of medical bacteria, third edition, University Press, Cambridge. $331 \mathrm{Pp}$.

Bartges, J.W. 2004. Diagnosis of urinary tract infections. Vet. Clin. Small Anim. 34: 923933.

Benjamin, M.M. 1985. Outline of veterinary clinical pathology. Third edition. Indian reprint. Kalyani Publishers, New Delhi.pp.18-27

Blanco, L.J. and Bartges, J.W. 2001. Understanding and eradicating bacterial urinary tract infections. Vet. Med. 96: 776789. 
Bubenik, L.J., Hosgood, G.L., Waldron, D.R. and Snow, L.A. 2007. Frequency of urinary tract infection in catheterized dogs and comparison of bacterial culture and susceptibility testing results for catheterized and noncatheterized dogs with urinary tract infections. J.Am.Vet.Med.Assoc.231:893899

Cetin, C., Senturk, S., Kocabiyik, A.L., Temizel, M. and Ozel, E. 2003. Bacteriological examination of urine samples from dogs with symptoms of urinary tract infection. Turk. J. Anim. Sci. 27:1225-1229.

Cruickshank, R., Duguid, J.P., Marmion, B.P. and Swain, R.H.A. 1975. Cultural pattern of bacteria. Medical Microbiology. Twelfth edition. Churchill Livingstone, Edinburgh. 920p

Dowling (1996). Antimicrobial therapy of urinary tract infections. Can Vet J Volume 37, July 1996

Dunning, M. and Stonehewer, J. 2002. Urinary tract infections in small animals: therapeutic options and management of problem cases. In Pract.24: 518-527.

Fransson, B.A., Bergstrom, A., Wardrop, J. and Hagman, R. 2007. Assessment of three automated assays for C-reactive protein determination in dogs. Am. J. Vet. Res. 68:1281-1286

Gatoria, I.S., Saini, T.S., Rai, T.S. and Dwivedi, P.N. 2006. Comparison of three techniques for the diagnosis of urinary tract infections in dogs with urolithiasis. J. Small Anim. Pract. 47: 727-732.

Georgieva, T.M., Georgiev, I.P., Iliev, Y., Petrov, V.S., Vachkov, A., Kanelov, I.N. Tanev, S.I., Zaprayanova, D., Pavlov, A.I. and Eckersall, D. 2008. Blood serum concentrations of total proteins and main protein fractions in weaning rabbits experimentally infected with E. coli. Revue Med. Vet. 159: 431-436.
Kealy, K.J., McAllister, H. and Graham, J. 2011. The abdomen. Diagnostic radiology and ultrasonography of the dog and cat. Fifth edition. Elsevier, St. Louis, Missouri, pp.126-181.

Leveille, R., Biller, D.S. and Partington, B.P. 1992. Sonographic investigation of transitional cell carcinoma of the urinary bladder in small animals. Vet. Radiol. Ultrasound. 33:103-107.

Papini, R., Ebani, V.V., Cerri, D. and Guidi, G. 2006. Survey on bacterial isolates from dogs with urinary tract infections and their in vitro sensitivity. Revue.Med.Vet.157: 3541

Pierce-Hendry, S.A. and Dennis, J. 2010. Bacterial culture and antibiotic susceptibility testing. Comp. Cont. Educ. Pract.7:1-6

Schalm, O.W., Jain, N.C. and Corel, E.J. 1975. Veterinary haematology. Third edition. Lea and Febiger, Philadelphia.p.647

Squires, R. 1994. Tackling the problem of proteinuria. In Pract.16:30-36.

Throop, J.L., Kerl, M.E. and Cohn, L.A. 2004. Albumin in health and disease: causes and treatment of hypoalbuminemia. Compdend.940-949.

Yogeshpriya Somu, Usha Narayana Pillai, Ajithkumar and Alex PC 2015a. Evaluation of physico-chemical and microscopical changes of urine in dogs with urinary tract infection. International Journal of Food, Agriculture and Veterinary Sciences. 2015 Vol. 5 (3). 14-17

Yogeshpriya, S., Usha N. Pillai, Ajithkumar, S. and Madhavan Unny, N. Biofilm production of $S$. aureus associated with canine urinary tract infection. International journal of science and nature. 7 (4) 2016b: 891-893

\section{How to cite this article:}

Yogeshpriya, S., Usha Narayana Pillai, S. Ajithkumar and Madhavan Unny. 2018. Clinico-HaematoBiochemical Profile of Dogs with Urinary Tract Infection: A Retrospective Study of 32 Cases (20102012). Int.J.Curr.Microbiol.App.Sci. 7(09): 2797-2802.

doi: https://doi.org/10.20546/ijcmas.2018.709.347 